\title{
Comprehensive assessment of soil quality for landscape and urban management
}

\author{
Robert R. Schindelbeck ${ }^{a}$, Harold M. van Es ${ }^{a}, *$, George S. Abawi ${ }^{b}$, David W. Wolfe ${ }^{c}$, \\ Thomas L. Whitlow ${ }^{\mathrm{c}}$, Beth K. Gugino ${ }^{\mathrm{b}}$, Omololu J. Idowu ${ }^{\mathrm{a}}$, Bianca N. Moebius-Clune ${ }^{\mathrm{a}}$ \\ a Department of Crop and Soil Sciences, 1005 Bradfield Hall, Cornell University, Ithaca, NY 14853-1901, USA \\ b Department of Plant Pathology, New York State Agricultural Experiment Station, Geneva, NY, USA \\ c Department of Horticulture, Cornell University, Ithaca, NY, USA
}

\section{A R T I C L E I N F O}

\section{Article history:}

Available online 8 October 2008

Keywords:

Soil quality

Soil health

Comprehensive soil testing

Soil remediation

\begin{abstract}
A B S T R A C T
Approaches to measuring air and water quality are well established, but soil quality assessment protocols to be used in landscape monitoring efforts are largely non-existent. The concept of soil quality represents the integration of the physical, biological, and chemical aspects of soils. Limited attention has been given to the holistic assessment of soil quality in landscape and urban planning, as it is typically addressed only through chemical analyses. We describe the process used for the selection of soil quality indicators that are being offered as part of the new Cornell Soil Health Test. Over 1500 samples were collected from agricultural landscapes, including controlled experiments, and analyzed for 39 potential soil quality indicators. Four physical and four biological soil indicators were selected based on sensitivity to management, relevance to functional soil processes, ease and cost of sampling, and cost of analysis. Seven chemical indicators were selected as they constitute the standard soil fertility test. For potentially contaminated sites, additional chemical indicators were considered through a total elemental analysis. Test reports were developed to allow for overall soil quality assessment and the identification of specific soil constraints that may be remedied through management practices. The use of the new soil quality test is exemplified for three landscape scenarios in New York State: a vegetable farm, a town park, and a vacant urban lot. The protocol provides a comprehensive assessment of the soil's ability to perform critical environmental functions at a relatively modest cost, and it helps target management and remediation approaches.
\end{abstract}

(C) 2008 Elsevier B.V. All rights reserved.

\section{Introduction}

\subsection{Landscapes and soils}

Landscapes are regionally cohesive spatial units that are composed of interacting land uses and common landforms, soils, hydrology, climate, biota and human influences (after Gregorich et al., 2001). A healthy landscape is a multifunctional and safe environment capable of supporting diverse and high quality life forms. The three fundamental resources that support such environments are air, water and soil. Approaches to measuring air and water quality are generally well established and have largely been standardized around the world (Riley, 2001). Soil quality, however, has only recently been considered and standard protocols for extensive monitoring are largely non-existent. Soil additionally poses greater sampling challenges as, unlike water and air, the medium does not flow or mix and has high spatial and temporal variability (van Es et al., 1999).

\footnotetext{
* Corresponding author. Tel.: +1 607 2555629; fax: +1 6072553207.

E-mail address: hmv1@cornell.edu (H.M. van Es).
}

Soil quality degradation is manifest in the pressing problems of erosion, compaction, acidification, organic matter losses, desertification, and chemical contamination, which reduce its capacity for production of food, fiber, and energy. It has also contributed to reduced ecosystem functioning through water contamination, altered regional water balances, and lower diversity and richness of plant and animal species. In addition, global climate change is increasing the variability of weather conditions worldwide, and soil is a critical buffer medium for hydrologic and biogeochemical processes, potentially mitigating the effects of extreme weather conditions and uncertainty in the availability of water resources (Larson and Pierce, 1991).

\subsection{Soil quality and health}

Doran and Parkin (1994) defined soil quality as "the capacity of a soil to function, within ecosystem and land use boundaries, to sustain productivity, maintain environmental quality, and promote plant and animal health". It includes an inherent and a dynamic component (Carter, 2002; Larson and Pierce, 1991). The former is an expression of the soil forming factors (Brady and Weil, 2002), often documented by soil surveys (Soil Survey Division Staff, 1993). 
Dynamic soil quality, however, generally refers to the condition of soil that is changeable in a short period of time by human impacts (Carter, 2002; Karlen et al., 1997; Mausbach and Seybold, 1998; Wienhold et al., 2004). With farmer and lay audiences, the term "soil health" is often preferred when referring to this dynamic soil quality concept as it connotes a holistic approach to soil management (Idowu et al., 2007).

Soil quality integrates physical, chemical and biological components and processes and the interactions among them (Karlen et al., 2001; Dexter, 2004a). The physical structure of soil plays an integral role in controlling chemical and biological processes (Dexter and Czyz, 2000; Dexter, 2004b), and it also affects infiltration, aeration, and drainage (Kemper and Rosenau, 1986) as well as better root penetration and proliferation (Czyz, 2004). Alternatively, biological and chemical processes, such as root growth, organic matter input, macro fauna activity, and bacterial and fungal proliferation influence pore size distribution, density, and stability of the soil's structure (Wright and Upadhyaya, 1998; Amezketa, 1999; Magdoff and van Es, 2000). Soil-impacting practices such as tillage, traffic, plant cover systems, and organic and inorganic inputs (accidental or deliberate) strongly influence all components of soil quality and, thus, ecological functioning (Doran and Parkin, 1996; Guérif et al., 2001).

\subsection{Soil quality assessment and indicators}

New regulations have catalyzed the proliferation of various indicators and "environmental report cards" for assessing vulnerability and improvement towards sustainability (Riley, 2001). There are several criteria by which the suitability of indicators can be judged, including relevance, accessibility to users, and measurability (Nambiar et al., 2001). Once relevant indicators have been identified, the researcher can set criteria and thresholds by which to assess the environment and the level of performance relative to a justifiable standard (Manhoudt et al., 2005, Sepp and Bastian, 2007). In a review of eleven agricultural case studies using six different types of environmental assessment, Payraudeau and van der Werf (2005) concluded that the most powerful indicators consider the effects on productivity and the environment.

Indicators can be used to represent complex processes, and many have been developed for ecological and environmental analyses, e.g., for nutrient loss potential on fields (Lemunyon and Gilbert, 1993; Williams and Kissel, 1991) and the environmental impacts of different land use mosaics (e.g., Medvedev, 1994). Soil quality cannot be measured directly, but soil properties that are sensitive to changes in management can be used as indicators (Brejda et al., 2000). Methods for measuring individual indicators and minimum data sets (da Silva et al., 1997; Dexter, 2004c) and for calculating indices from groups of indicators (Karlen and Stott, 1994, Andrews et al., 2004) are being developed for the purposes of monitoring soil quality over time and evaluating the sustainability of agricultural and land management practices. However, such tests must not be too costly so as not to prevent widespread adoption beyond the research domain.

Limited experience exists with the use of inexpensive methods (other than for standard agricultural soil tests) that might be widely adopted by governments, farmers, and consultants for comprehensive soil quality assessment. The standard agricultural soil tests focus on a limited number of soil chemical indicators that are critical to crop nutrition. They have provided farmers and consultants around the world with relevant information for nutrient and lime management. In a more holistic soil quality paradigm, soil tests are needed to provide an integrated assessment of the triad of soil quality domains (physical, biological and chemical). Such a soil test would need to involve soil quality indicators that represent soil processes relevant to soil functions, and it would also provide information that is useful for practical soil management. In this context, soil quality is best assessed through soil properties that are sensitive to changes in management (Andrews and Carroll, 2001; Brejda et al., 2000; Doran and Parkin, 1994; Larson and Pierce, 1991).

Sojka and Upchurch (1999) argued that the optimization of processes may require different interpretations of soil quality indicators for the different soil functions. Another approach is to place the emphasis on the value of the information itself and to identify soil constraints to aid in the selection of management solutions (Idowu et al., 2007). The interpretation of the test results thus requires professional judgment and placement into the context of the land use objectives. For example, soil quality test results from a dairy farm require different interpretations and management approaches than for a viticulture operation (White, 2003), or an urban park.

The objective of this paper is to discuss the process of the selection of key soil quality indicators, as implemented through the new Cornell soil health test, and to highlight the utility of the test through three example cases.

\section{Cornell soil health test development}

\subsection{Approach}

The development of the Cornell soil health test involved a triage process for potential soil quality indicators and streamlining of methodologies. The new three-faceted soil quality test was envisioned to provide critical quantitative information that would allow for better management and protection of soil resources in rural and urban areas. Specifically, the test was developed for the following reasons:

- Improved soil inventory assessment: Evaluation of dynamic soil quality in addition to the traditional genetic (inherent) soil quality as reported in soil surveys.

- Land valuation: Effective quantification of soil quality allows for better assessment of the monetary value of land for purchasing and rental transactions, thereby facilitating financial rewards for good land management.

- Targeting management practices: Measured soil constraints can be addressed with high likelihood for positive results, while no investments are needed in unsubstantiated problems.

- Quantifying soil degradation or aggradation from management: Agencies, farmers, consultants, and applied researchers can evaluate the soil quality benefits resulting from changes in management practices. Governments can link green payments to soil quality improvements.

- Education: Site-specific soil quality information facilitates discussion on soil management and care.

Thirty-nine potential soil health indicators were evaluated (Table 1), which were selected based on expert knowledge and the literature. The suitability of the soil properties as quality indicators was evaluated through samples from (i) long-term, replicated research experiments related to tillage, rotation, and cover cropping studies, (ii) commercial farms that provided real-world perspective under the range of soil management conditions in New York State, and (iii) selected non-agricultural sites. The commercial farms included grain, dairy, vegetable, and fruit operations and a wide range of soil types. In total, over 1500 samples were included in the evaluation, although not all 39 properties were measured on all samples. For the controlled experiments, soil samples were collected four times over the course of the 2004 growing season to evaluate within-season variability. 
Table 1

Thirty-nine soil health indicators evaluated for the Cornell soil health test

\begin{tabular}{|c|c|c|}
\hline Physical indicators & Biological indicators & $\begin{array}{l}\text { Chemical } \\
\text { indicators }\end{array}$ \\
\hline $\begin{array}{l}\text { Bulk density } \\
\text { Macro-porosity } \\
\text { Meso-porosity } \\
\text { Micro-porosity } \\
\text { Available water capacity } \\
\text { Residual porosity } \\
\text { Penetration resistance at } 10 \mathrm{kPa} \\
\text { Saturated hydraulic conductivity } \\
\text { Dry aggregate size }(<0.25 \mathrm{~mm}) \\
\text { Dry aggregate size }(0.25-2 \mathrm{~mm}) \\
\text { Dry aggregate size }(2-8 \mathrm{~mm}) \\
\text { Wet aggregate stability }(0.25-2 \mathrm{~mm}) \\
\text { Wet aggregate stability }(2-8 \mathrm{~mm}) \\
\text { Surface hardness (penetrometer) } \\
\text { Subsurface hardness (penetrometer) } \\
\text { Field infiltrability }\end{array}$ & $\begin{array}{l}\text { Root health assessment } \\
\text { Organic matter content } \\
\text { Beneficial nematode } \\
\text { Population } \\
\text { Parasitic nematode } \\
\text { population } \\
\text { Potential mineralizable } \\
\text { Nitrogen } \\
\text { Decomposition rate } \\
\text { Particulate organic matter } \\
\text { Active carbon test } \\
\text { Weed seed bank } \\
\text { Microbial respiration rate } \\
\text { Glomalin content }\end{array}$ & $\begin{array}{l}\mathrm{pH} \\
\text { Phosphorus } \\
\text { Potassium } \\
\text { Magnesium } \\
\text { Calcium } \\
\text { Iron } \\
\text { Aluminum } \\
\text { Manganese } \\
\text { Zinc } \\
\text { Copper }\end{array}$ \\
\hline
\end{tabular}

\subsection{Sampling and analysis}

For all management units (farmer fields or research plots), two undisturbed soil core samples were collected in central areas of fields and plots (the latter being replicated in all cases) from the depth of 5-66 mm using stainless steel rings (61 mm height, $72 \mathrm{~mm}$ ID, $1.5 \mathrm{~mm}$ wall thickness). Disturbed samples were collected from depths of 5-150 mm using trowels, assuring against depth bias. All samples were stored at $2{ }^{\circ} \mathrm{C}$ until analysis.

The physical tests were based on standard methodology (Moebius et al., 2007), except for wet aggregate stability, which involved the application of simulated rainfall of known energy (Ogden et al., 1997) to aggregates on sieves. The biological test also mostly involved established methods. The decomposition rate was based on loss of filter paper volume after 3-week soil incubation. The active carbon test involved a $\mathrm{KMnO}_{4}$ oxidation procedure based on work by Weil et al. (2003). The root health assessment involved a bioassay method where snap bean seeds are planted in the sampled soil material and root damage is rated based on root morphological features (Abawi and Widmer, 2000).

Analysis of the chemical indicators was based on the standard soil fertility test offered by the Cornell Nutrient Analysis Laboratory. The available nutrients were extracted with Morgan's solution, a sodium acetate/acetic acid solution, buffered at $\mathrm{pH} 4.8$. The extraction slurry was filtered and analyzed for $\mathrm{K}, \mathrm{Ca}, \mathrm{Mg}, \mathrm{Fe}, \mathrm{Al}, \mathrm{Mn}$, and $\mathrm{Zn}$ on an inductively coupled plasma spectrometer (ICP), and plant-available $\mathrm{PO}_{4}$-P was measured using an automated rapid flow analyzer. $\mathrm{pH}$ was determined from a 1:1 soil:water mix using a standard $\mathrm{pH}$ meter and electrodes. Some samples with potential chemical contamination concerns were additionally subjected to an elemental analysis using complete $\mathrm{HNO}_{3}$ digestion combined with ICP analysis.

\subsection{Indicator Selection}

The general criteria used for physical and biological indicator selection into the test included:

- Sensitivity to management, i.e., frequency of significant treatment effects in the controlled experiments and directional consistency of these effects.

- Precision of measurement method, i.e., residual errors from analyses of variance.

- Relevance to important functional soil processes such as aeration, water infiltration/transmission, water retention, root prolifera-
Table 2

Soil quality indicators included in the standard Cornell soil health test, and associated processes

\begin{tabular}{|c|c|}
\hline Soil indicator & Soil process \\
\hline \multicolumn{2}{|l|}{ Physical } \\
\hline Soil texture & All \\
\hline Aggregate stability & $\begin{array}{l}\text { Aeration, infiltration, shallow } \\
\text { rooting, crusting }\end{array}$ \\
\hline Available water capacity & Water retention \\
\hline Surface hardness & Rooting at in plow layer \\
\hline Subsurface hardness & $\begin{array}{l}\text { Rooting at depth, internal } \\
\text { drainage }\end{array}$ \\
\hline \multicolumn{2}{|l|}{ Biological } \\
\hline Organic matter content & $\begin{array}{l}\text { Energy } / \mathrm{C} \text { storage, water and } \\
\text { nutrient retention }\end{array}$ \\
\hline Active carbon content & $\begin{array}{l}\text { Organic material to support } \\
\text { biological functions }\end{array}$ \\
\hline Potentially mineralizable nitrogen & Ability to supply $\mathrm{N}$ \\
\hline Root rot rating & Soil-borne pest pressure \\
\hline \multicolumn{2}{|l|}{ Chemical-standard } \\
\hline $\mathrm{pH}$ & Toxicity, nutrient availability \\
\hline Extractable P & $\begin{array}{l}\text { P availability, environmental } \\
\text { loss potential }\end{array}$ \\
\hline Extractable K & K availability \\
\hline Minor Element Contents & $\begin{array}{l}\text { Micronutrient availability, } \\
\text { elemental imbalances, toxicity }\end{array}$ \\
\hline
\end{tabular}

tion, nitrogen mineralization, development of root diseases, etc.

- Ease and cost of sampling

- Cost of analysis.

Qualitative ratings for sensitivity to sampling error and ability to represent soil functional processes were assigned using relationships established in the literature (Andrews et al., 2004; Larson and Pierce, 1991; Luxmoore, 1981) as well as experience from this study. Quantitative data were obtained from experimental analyses (e.g. consistency of treatment effects and reproducibility) and sample processing (e.g., cost of labor, equipment and supplies). Many of the physical soil properties were rejected as suitable indicators due to the requirement for undisturbed samples or due to high variability. Many soil biological indicators were rejected due to the high cost of analysis, often associated with labor.

The nine soil chemical indicators were all adopted in the comprehensive soil quality test because they are part of a wellestablished standard soil fertility analysis procedure that is widely used at reasonable cost. The elemental analysis based on $\mathrm{HNO}_{3}$ digestion was included in the standard test for samples where contamination was expected. It is currently handled separately in the interpretation of the soil quality test as it is an additional expense that is not necessary for the majority of soils.

\subsection{Selected test indicators}

Table 2 shows the physical, biological, and chemical indicators that have been selected for the soil health test. These soil measurements can be considered as indicators of critical soil processes (e.g., aeration, infiltration, water and nutrient retention, root proliferation, $\mathrm{N}$ mineralization, toxicity prevention, pest suppression, etc.), which, in turn, relate to soil functions such as plant production, landscape water partitioning, and habitat support. The standard soil health test thereby evaluates the soil's ability to accommodate ecosystem functioning within landscapes. The optional elemental analysis additionally provides information on human, animal and plant toxicity concerns. Soil texture is an integrative property and provides the basis for interpretation of results through scoring functions (discussed below). Root health assessment is an integrative biological measurement related to overall pressure from soil-borne 
disease organisms (Abawi and Widmer, 2000). The minor elements of the chemical analysis were grouped to prevent a bias of the soil health assessment in favor of chemical quality.

The indicators are measured based on a composite disturbed sample, which we recommend be obtained from two locations nested within five sites on a land unit (field, lot, etc.). The test also includes penetrometer measurements as the only in-field assessment. Although it is widely regarded as an important physical indicator, bulk density was not included because it was found to be imprecise (Moebius et al., 2007) and generally strongly correlated with other physical indicators in the test (and, therefore, mostly redundant). Moreover, the use of ring samplers for bulk density proved to be a serious obstacle with field practitioners and technicians. Therefore, the reliability of the results was questionable due to frequent improper sampling, especially with soils containing coarse fragments. Based on an economic analysis (Moebius et al., 2007), the cost of the standard test was determined to be less than US $\$ 50$. The optional elemental analysis adds approximately $\$ 15$ to the cost.

Soil samples are best collected during the early spring (15 April-1 June), preferably prior to tillage in agricultural fields. Some indicators have been shown to have significant within-season variability (Moebius et al., 2007), and soil management practices can be a confounding influence for physical and biological soil indicators. Also, spring sampling is facilitated by favorable soil water conditions (generally near field capacity), and biological assessments benefit from the more uniform conditions following over-wintering.

\subsection{Data interpretation and scoring curves}

Effective use of soil health test results requires the development of an interpretive framework for the measured data. The general approach of Andrews et al. (2004) was applied for this purpose, and scoring functions were developed for all soil indicators (except texture) to rate test results. Different scoring functions were developed for the three main textural classes (sand, silt, and clay) hence the necessity to determine soil texture during the testing procedure (which is done by the rapid "feel method"; Brady and Weil, 2002).

The scoring functions were defined in the simple linear-plateau framework, as no justification existed for more complex curvilinear functions. Three types of scoring functions were considered (Fig. 1), "more is better", "less is better", and "optimum". The critical cutoff values for the highest and lowest curves were developed based on the frequency distribution of data generated from the indicators selection process. The 25 th and 75 th percentiles of the distribution curve were generally taken as the extreme values for the linear model where scores increase from 1 to 10 , i.e., test results with values less than the 25th percentile were given scores of 1 , and those with values greater than the 75th percentile were given scores of 10 . This approach was evaluated relative to literature reports (e.g., Andrews et al., 2004), minor modifications were made in

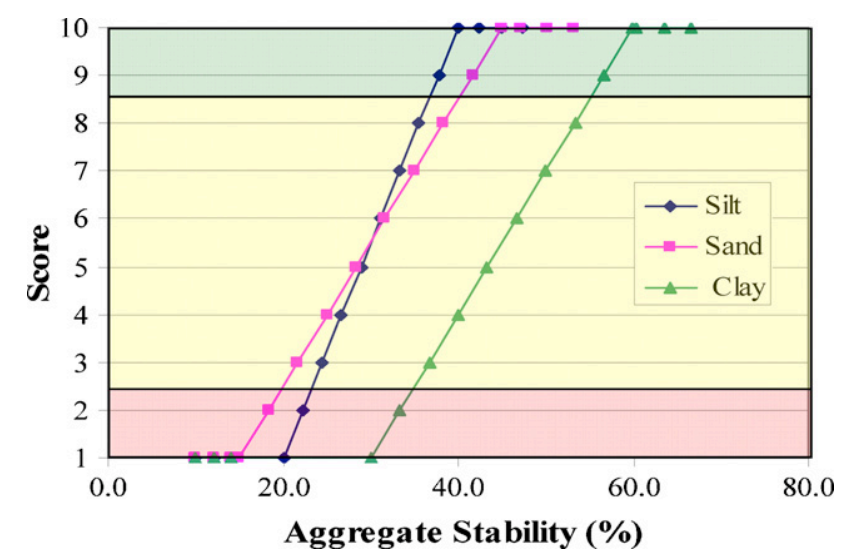

Fig. 2. Scoring curves used for interpretation of aggregate stability data for sand, silt, and clay soils.

some cases. Future modifications are anticipated as the soil quality database expands.

The scoring curves for aggregate stability (Fig. 2) are examples of the "more is better" relationship. A low score of 1 is assigned to results of less than $15 \%, 20 \%$, and $30 \%$ for sand, silt and clay soils, respectively. Respective active carbon values of greater than $40 \%$, $35 \%$, and $60 \%$ are scored as 10 , and intermediate values are linearly interpolated. Scoring curves for other indicators are reported in Gugino et al. (2007).

\subsection{Soil health test report}

The standard soil health test report was designed for practitioner audiences, and it facilitates both integrative assessment and targeted identification of soil constraints. This is accomplished through the combined use of quantitative data and color coding (Fig. 3). The physical, biological, and chemical indicators are grouped by blue, green, and yellow colors, respectively. For each indicator, the measured value is reported as well as the associated score (using a scoring function). The latter is interpreted with colors such that scores of less than three receive a red code, scores greater than eight receive a green code, and those in between are coded yellow. This provides for an intuitive overview of the test report. If results are coded red, the associated soil constraints are also listed (Fig. 3). Finally, the percentile rating is shown for each indicator, based on the sample's ranking in the database of soil indicator measurements (Fig. 3). An overall soil health score is provided at the bottom of the report, which is standardized to a scale from 1 to 100. It is noted that the interpretation of the test results is generalized for agricultural systems and may require alternative interpretation in other cases. Hence, we recommend that the reports be interpreted by professional consultants and include consideration of additional site-specific information.

Soil management recommendations were developed to address specific soil management constraints in agricultural systems
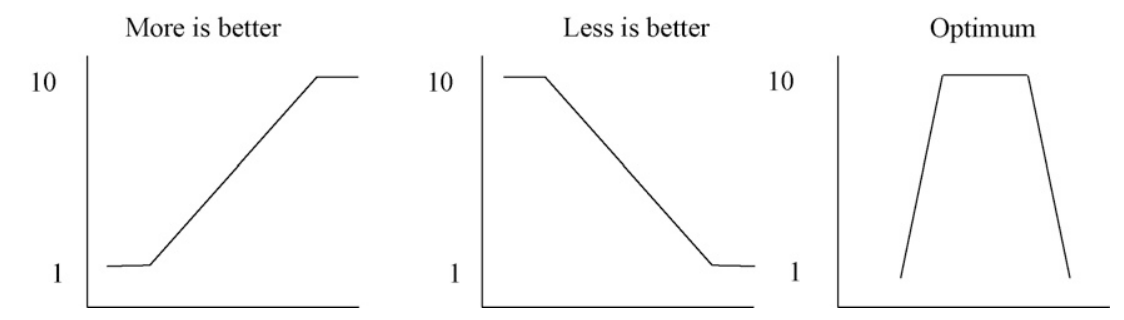

Fig. 1. Models of scoring curves used for the interpretation of measured values of soil quality indicators. 


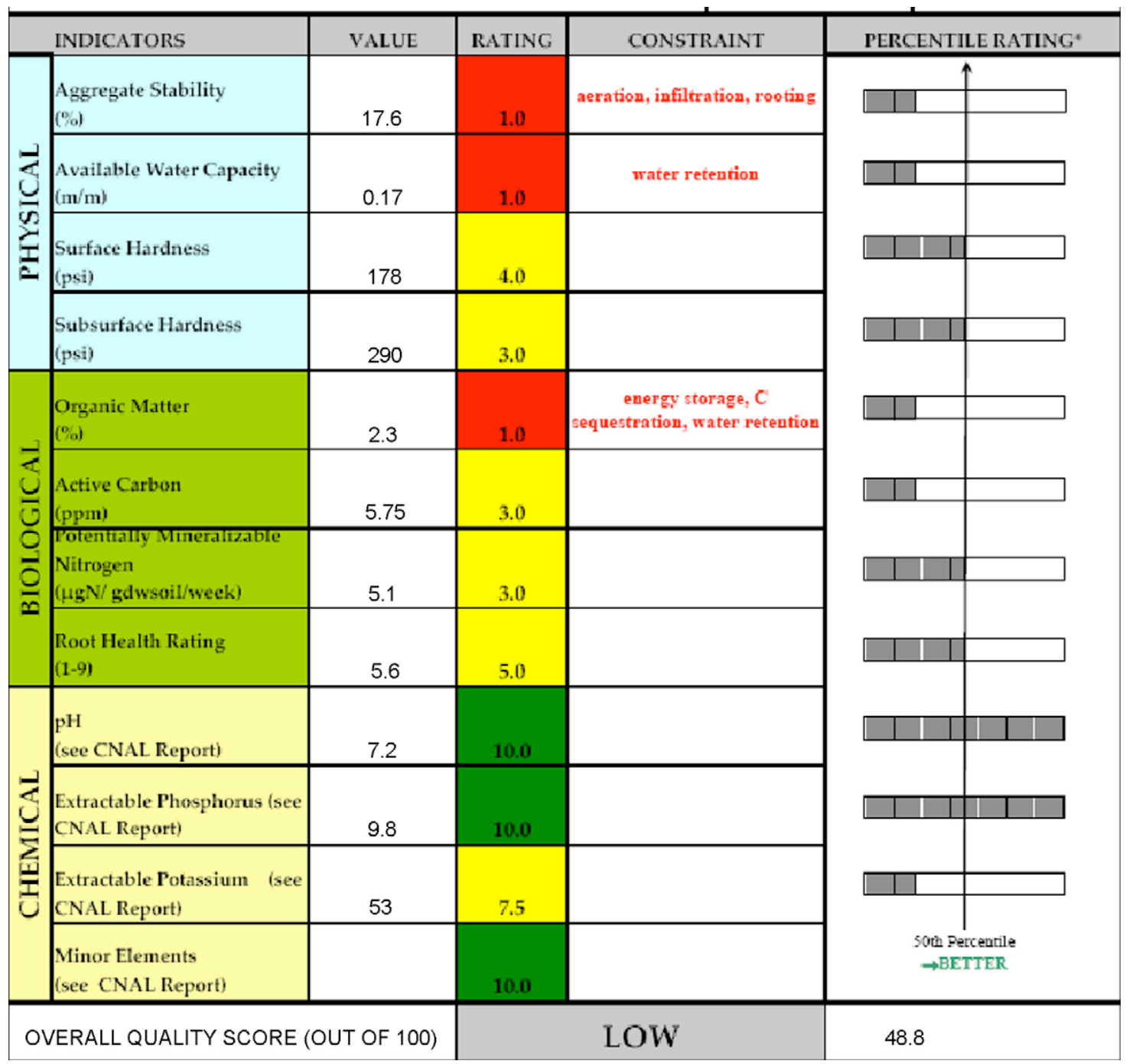

Fig. 3. Soil health test report for a field from a vegetable farm.

(Gugino et al., 2007), but they are still under development for nonagricultural uses. A training manual was developed that discusses the basic approaches to soil health assessment (including sampling methods and field and laboratory assessment protocols), the reporting and interpretation of the results, and the suggested management approaches. It can be accessed and downloaded from the Cornell Soil Health web site at http://soilhealth.cals.cornell.edu.

\section{Case studies}

Three case studies exemplify the use of the test for different land uses and management purposes. These illustrate the variety of conditions where soil quality analysis provides useful information to land managers, whether they are farmers, consultants or agencies.

\subsection{Vegetable farm}

The test report for a field from a farm near Geneva, NY $\left(42^{\circ} 52^{\prime} \mathrm{N}\right.$, $77^{\circ} 05^{\prime} \mathrm{W}$ ) on a glacial till-derived Honeoye-Lima silt loam (fineloamy, mixed, active, mesic Glossic Hapludalf; U.S. Soil Taxonomy, Soil Survey Staff, 1999) is shown in Fig. 3. The farm has been used for production of processing vegetables (cabbage, beets, etc.) using intensive tillage practices. It was left fallow during ownership transfer for a 3-year period (2000-2003). From 2004 to 2006, it was again used for production of vegetables (beets, sweet corn, snap beans) using conventional (moldboard plow) tillage.

The test report shows favorable results for the chemical indicators, as indicated by the high rating scores ( 7.5 or above). The remaining indicators, however, have low scores and, therefore, show evidence of low physical and biological soil quality. Very unfavorable results for aggregate stability, available water capacity, and organic matter content $(1,2$, and 1 , respectively) suggest both soil degradation from long-term intensive tillage and limited use of soilbuilding crops. Low to intermediate scores for active carbon, PNM, and root health $(3,2$, and 5 , respectively) indicate that the soil was biologically degraded and unbalanced. The scores for soil hardness (3-4) indicate a mild soil compaction problem. The overall score of 49.5 signifies considerable opportunity for improvement.

This report exemplifies the need for broader assessment of soil quality. Based on the traditional soil testing methodology, i.e., the chemical indicators, the soil appeared to be of good quality. This is commonly the case, as most farmers are diligent about submitting soil samples for nutrient analysis and subsequently correct deficiencies. Chemical constraints are readily remedied by application of inorganic chemicals, which generally provides instant results at a reasonable cost. In contrast, the lack of routine tests for soil physical and biological indicators has resulted in inadequate attention to these facets of the soil. Moreover, enhancing the 


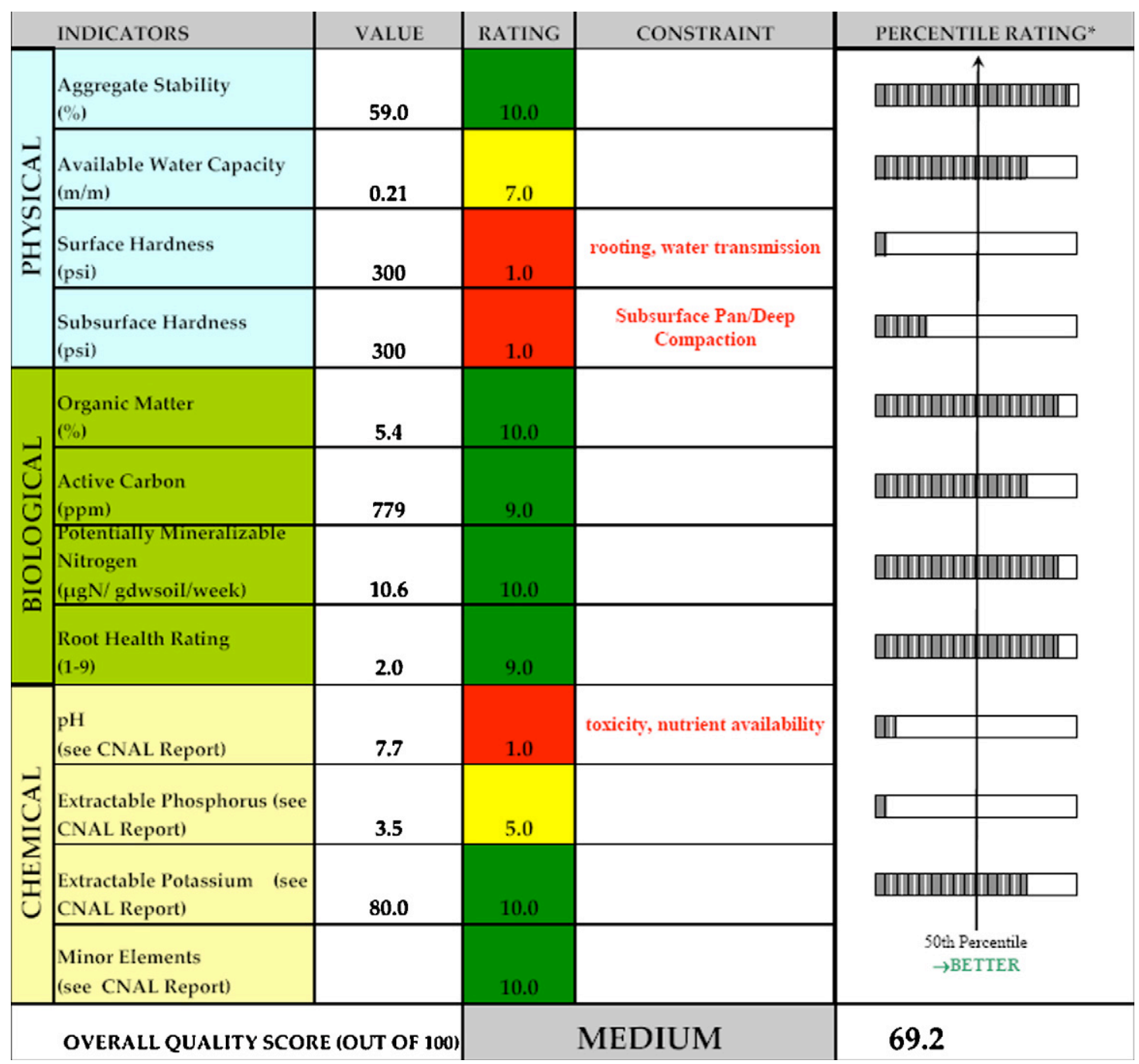

Fig. 4. Soil health test report for a grass field in a rural town park.

physical and biological quality of soils generally requires a longerterm commitment to improved soil management through practices such as conservation tillage, improved rotations, use of cover crops, and application of organic amendments, as discussed in Gugino et al. (2007). The soil health test therefore identifies, therefore, a broader set of constraints and provides farmers with information that allows for holistic soil management.

\subsection{Rural town park}

The soil health test report for soil material collected from a recreational field in a park owned by the municipality of Lansing, NY $\left(42^{\circ} 32^{\prime} \mathrm{N}, 76^{\circ} 32^{\prime} \mathrm{W}\right)$ is shown in Fig. 4. The park is located on a small delta to a glacial lake, and the soil is classified as a Genessee silt loam (fine-loamy, mixed, superactive, mesic Fluventic Eutrudepts; Soil Survey Staff, 1999). The area has been under grass for over 50 years and is extensively used for recreational purposes. The test report indicates that the soil scores high for all four biological indicators, aggregate stability, and available water capacity, which is presumably the result of a build-up of organic matter from long term untilled sod. The report indicates that soil hardness is high for both the surface and subsurface. This is presumably the result of foot and mower traffic, often at suboptimal conditions when the soil is readily compacted. It also contributes to an apparent problem with internal drainage at the site. The chemical test results indicate high $\mathrm{pH}$ values and suboptimal $\mathrm{K}$ levels. The elemental analysis for this site indicated that only $\mathrm{Pb}$ levels are elevated for this site (134 $\mathrm{mg} \mathrm{kg}^{-1}$ ) to a level above the $62 \mathrm{mg} \mathrm{kg}^{-1}$ standard in New York for unrestricted use sites (DEC, 2006; Table 3).

The soil health test report indicates that this soil is generally of good quality with an overall score of 69.2, but it also indicates that addressing a compaction problem and suboptimal chemical conditions will alleviate some constraints and make the site a higher-quality environment for recreational purposes and ecosystem services.

\subsection{Vacant urban lot}

Fig. 5 shows the soil health test report for a vacant urban lot in Baltimore, $\mathrm{MD}\left(39^{\circ} 17^{\prime} \mathrm{N}, 76^{\circ} 36^{\prime} \mathrm{W}\right)$. The site is located in an urban area where housing from the early 1900s has fallen into disrepair. The soil is mostly anthropogenic, or at least strongly influenced by human activities, unclassified, of mixed origin and of silty texture. The lot was vacant and mostly covered by a variety of weeds.

The test report indicates a very mixed picture on the quality of the soil material, with an overall score of 62.5. Although aggregate stability is high, available water capacity shows a low quality score, and soil hardness indicators are in the intermediate range. Both 
Table 3

Concentrations of selected inorganic elements from the whole-soil digestion analysis of the town park and urban lot samples, and the New York State Department of Environmental Conservation (DEC) standards for unrestricted use

\begin{tabular}{llll}
\hline Element & Town park $\left(\mathrm{mg} \mathrm{kg}^{-1}\right)$ & Urban lot $\left(\mathrm{mg} \mathrm{kg}^{-1}\right)$ & DEC standard \\
\hline As & 3.32 & $<$ det & 13 \\
Ba & 35.39 & 115.00 & 350 \\
Be & 0.24 & 0.72 & 7.2 \\
Cd & $<$ det & 0.53 & 2.5 \\
Co & 5.22 & 15.72 & \\
Cr & 10.06 & 61.96 & 30 \\
Cu & 14.22 & 31.17 & 50 \\
Hg & $<$ det & $<$ det & 0.18 \\
$\mathbf{L i}$ & 17.68 & 10.22 & \\
Mn & 286.51 & 560.79 & 1600 \\
Mo & $<$ det & $<$ det & 30 \\
Ni & 16.72 & 31.99 & 63 \\
$\mathbf{P b}$ & 134.49 & 150.07 & \\
Sb & $<$ det & 1.15 & 3.9 \\
Se & 1.77 & 5.48 & \\
Sr & 35.34 & 16.65 & 109 \\
Ti & 35.65 & 164.78 & \\
V & 17.40 & 79.86 & \\
$\mathbf{Z n}$ & 51.17 & 158.69 & \\
\hline
\end{tabular}

organic matter and active carbon contents are low, which appears inconsistent with the high aggregate stability levels. This suggests the presence of chemical soil stabilizing materials on the site, most likely of anthropogenic origin. A high score for PMN is presumably the result of the presence of leguminous weeds on the lot, and high root health is most likely related to the lack of host plants for snap bean pathogens, which would likely be the case for urban lots, except when they are used as vegetable gardens. The chemical indicators show inadequate P levels.

The elemental analysis showed that several chemical contaminants were at elevated levels, and most were also higher than in the town park case (Table 3). The main concerns are with $\mathrm{Cr}, \mathrm{Pb}$, $\mathrm{Ni}$, and $\mathrm{Zn}$, which are all above the standard for unrestricted use in New York State (DEC, 2006).

Based on the identified constraints for this site, soil quality can be improved through the addition of organic matter (e.g., compost) or capping the surface with topsoil material. This will increase organic matter and active carbon levels, as well as available water capacity (water retention). This will also add $\mathrm{P}$ to the soil, although some additional fertilizer may be required, depending on the $\mathrm{P}$ content of the organic material or topsoil. In general, adding fresh topsoil to cap the soil material, possibly with additional surface mulch, is strongly preferred to mixing in organic material because the mulch will provide a physical barrier from the tested soil

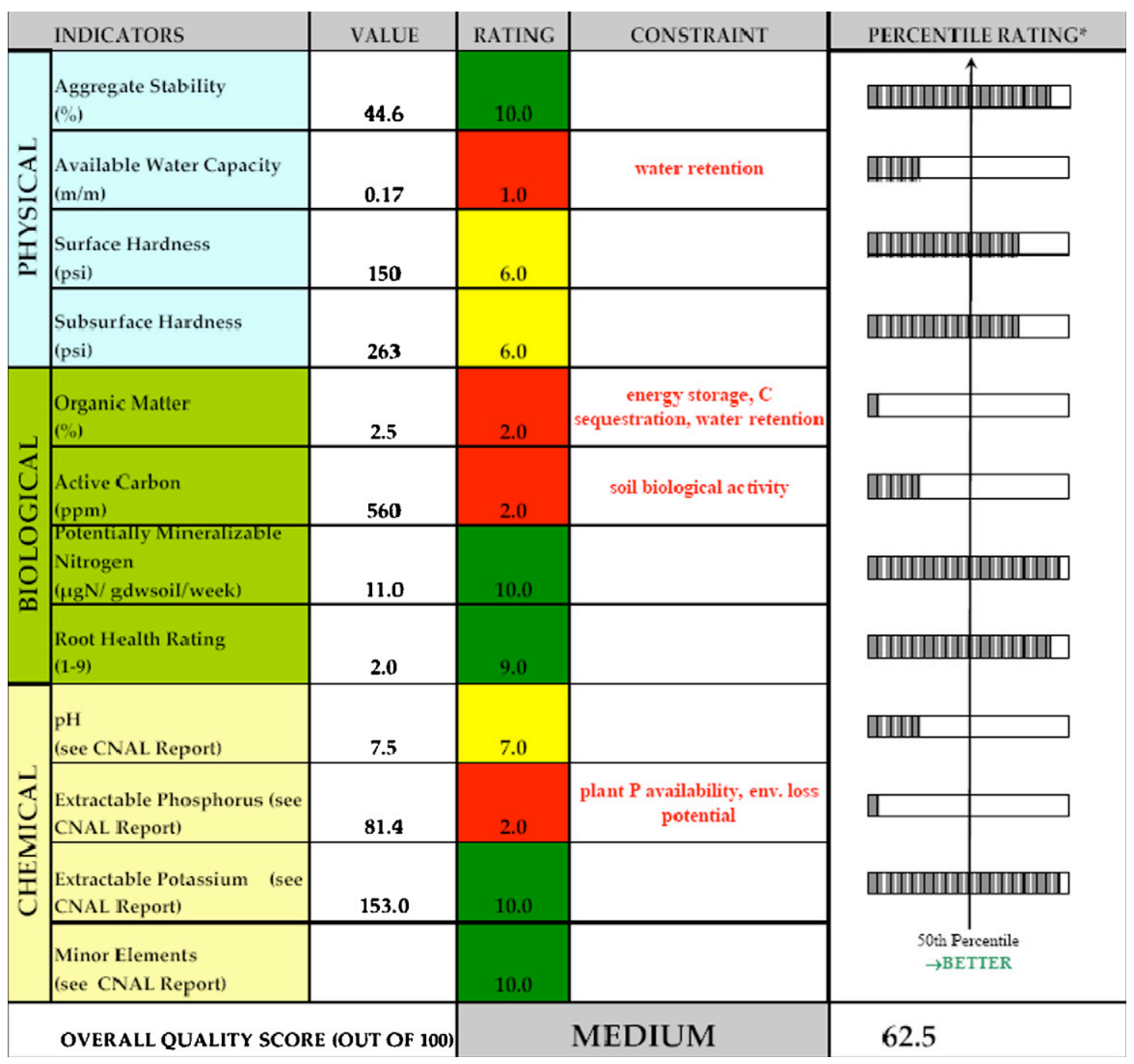

Fig. 5. Soil health test report for a vacant urban lot. 
material and reduce concerns about heavy metal levels, especially through dust or direct ingestion by infants. If future use of this site includes food production (e.g., vegetable gardens), the elevated metal levels should be considered, perhaps through re-testing after site remediation.

\section{Conclusion}

Soil health management requires a comprehensive approach that recognizes the physical, biological, and chemical processes in soils. In this context, the development of an inexpensive comprehensive soil quality test was seen as a priority to allow more widespread soil monitoring and better management decisions. A set of indicators was selected to represent an integrative assessment of soil quality, which is now being offered on a for-fee basis. The test is a significant step forward from conventional soil tests, which focus exclusively on chemical indicators. The use of a holistic test that provides information of all three aspects of soils (physical, biological, and chemical) provides a more meaningful approach to monitoring soil quality and it provides farmers, consultants and agencies with a tool to identify soil constraints and to target management practices or remediation strategies.

\section{Acknowledgements}

We acknowledge support from the USDA Northeast Sustainable Agriculture Research and Education Program (USDA 2003-386012985), the Northern New York Agricultural Development Program, and USDA-Hatch funds.

\section{References}

Abawi, G.S., Widmer, T.L., 2000. Impact of soil health management practices on soilborne pathogens, nematodes and root diseases of vegetable crops. Appl. Soil Ecol. 15, 37-47.

Amezketa, E., 1999. Soil aggregate stability: a review. J. Sust. Agricul. 14, 83-151.

Andrews, S.S., Carroll, C.R., 2001. Designing a soil quality assessment tool for sustainable agroecosystem management. Ecol. Appl. 11, 1573-1585.

Andrews, S.S., Karlen, D.L., Cambardella, C.A., 2004. The soil management assessment framework: a quantitative soil quality evaluation method. Soil Sci. Soc. Am. J. 68, 1945-1962.

Brady, N.C., Weil, R.R., 2002. The Nature and Properties of Soils, 13th ed. PrenticeHall, Upper Saddle River, NJ.

Brejda, J.J., Moorman, T.B., Karlen, D.L., Dao, T.H., 2000. Identification of regional soil quality factors and indicators. I. Central and southern high plains. Soil Sci. Soc. Am. J. 64, 2115-2124.

Carter, M.R., 2002. Soil quality for sustainable land management: organic matter and aggregation interactions that maintain soil functions. Agron. J. 94, 38-47.

Czyz, E.A., 2004. Effects of traffic on soil aeration, bulk density and growth of spring barley. Soil Till. Res. 79, 153-166.

da Silva, A.P., Kay, B.D., Perfect, E., 1997. Management versus inherent soil properties effects on bulk density and relative compaction. Soil Till. Res. 44, 81-93.

DEC, 2006. 6 NYCRR PART 375 Environmental Remediation Programs. Subparts 375-1 to 375-4 and 375-6. New York State Department of Environmental Conservation, Albany, NY.

Dexter, A.R., 2004a. Soil physical quality. Part I. Theory, effects of soil texture, density, and organic matter, and effects on root growth. Geoderma 120, 201-214.

Dexter, A.R., 2004b. Soil physical quality-preface. Soil Till. Res. 79, 129-130.

Dexter, A.R., 2004c. Soil physical quality. Part II. Friability, tillage, tilth and hardsetting. Geoderma 120, 215-225.

Dexter, A.R., Czyz, E.A., 2000. Soil physical quality and the effects of management In: Wilson, M.J., Maliszewska-Kordybach, B. (Eds.), Soil Quality, Sustainable Agriculture, and Environmental Security in Central and Eastern Europe. Published in cooperation with NATO Scientific Affairs Division. Kluwer Academic Publishers, Dordrecht, Boston, pp. 153-165.

Doran, J.W., Parkin, T.B., 1994. Defining and assessing soil quality. In: Doran, J.W., Coleman, D.C., Bezdicek, D.F., Stewart, B.A. (Eds.), Defining Soil Quality for a Sustainable Environment. Special Publication No. 35. Soil Science Society of America, Madison, WI, pp. 3-21.

Doran, J.W., Parkin, T.B., 1996. Quantitative indicators of soil quality: a minimum data set. In: Doran, J.W., Jones, A. (Eds.), Methods for assessing soil quality. Special Publication No. 49. Soil Science Society of America, Madison, WI, pp. 25-37.

Gregorich, E.G., Turchanek, L.W., Carter, M.R., Angers, D.A. (Eds.), 2001. Soil and Environmental Science Dictionary. Canadian Society of Soil Science, CRC Press, Boca Raton.
Guérif, J., Richard, G., Durr, C., Machet, J.M., Recous, S., Roger-Estrade, J., 2001. A review of tillage effects on crop residue management, seedbed conditions, and seedling establishment. Soil Till. Res. 61, 13-32.

Gugino, B.K., Idowu, O.J., Schindelbeck, R.R., van Es, H.M., Wolfe, D.W., Thies, J.E., et al., 2007. Cornell soil health assessment training manual (Version 1.2.). Cornell University, Geneva, NY.

Idowu, O.J., van Es, H., Schindelbeck, R., Abawi, G., Wolfe, D., Thies, J., et al., 2007. The new Cornell soil health test: Protocols and interpretation. What's Cropping Up? 17, 6-7. (Retrieved from http://www.css.cornell.edu/ extension/WCU/Vol17No12007Jan-Feb.pdf).

Karlen, D.L., Mausbach, M.J., Doran, J.W., Cline, R.G., Harris, R.F., Schuman, G.E., 1997. Soil quality: a concept, definition, and framework for evaluation. Soil Sci. Soc. Am. J. 61, 4-10.

Karlen, D.L., Stott, D.E., 1994. A framework for evaluating physical and chemical indicators of soil quality. In: Doran, J.W.E., Coleman, D.C., Bezdicek, D.F., Stewart, B.A (Eds.), Defining Soil Quality for a Sustainable Environment. Special Publication No. 35. Soil Science Society of America, Madison, WI, pp. 53-72.

Karlen, D.L., Andrews, S.S., Doran, J.W., 2001. Soil quality: current concepts and applications. Adv. Agron. 74, 1-40.

Kemper, W.D., Rosenau, R.C., 1986. Aggregate stability and size distribution. In: Klute, A. (Ed.), Methods of Soil Analysis. Part I. Physical and Mineralogical Methods, second ed. Soil Science Society of America, Madison, WI, pp. 425442 .

Larson, W.E., Pierce, F.J., 1991. Conservation and enhancement of soil quality, evaluation for sustainable land management in the developing world. In: IBSRAM Proceedings, No. 12, vol. 2. International Board for Soil Research and Management, Bangkok, pp. 175-203.

Lemunyon, J.L., Gilbert, R.G., 1993. Concept and need for a phosphorus assessment tool. J. Prod. Agric. 6, 483-486.

Luxmoore, R.J., 1981. Micro-, meso-, and macroporosity of soil. Soil Sci. Soc. Am. J. $45,671$.

Magdoff, F., van Es, H., 2000. Building soils for better crops. In: Sustainable Agriculture Network, second ed. Sustainable Agriculture Publications, Burlington, VT.

Manhoudt, A.G.E., Udo de Haes, H.A., de Snoo, G.R., 2005. An indicator of plant species richness of semi-natural habitats and crops on Arabic farms. Agric. Ecosyst. Environ. 109, 166-174.

Mausbach, M.J., Seybold, C.A., 1998. Assessment of soil quality. In: Lal, R. (Ed.), Soil Quality and Agricultural Sustainability. Ann Arbor Press, Chelsea, MI, pp. 3343.

Medvedev, V.W., 1994. Evaluation of agrolandscape predisposition to anthropogenic transformations. In: Ryszkowski, L., Balazy, S. (Eds.), Functional appraisal of agricultural landscape in Europe. Research Centre for Agriculture and Forest Environment, Poznan, Poland.

Moebius, B.N., van Es, H.M., Schindelbeck, R.R., Idowu, J.O., Clune, D.J., Thies, J.E. 2007. Evaluation of laboratory-measured soil physical properties as indicators of soil quality. Soil Sci. 172, 895-912.

Nambiar, K.K.M., Gupta, A.P., Fu, Q., Li, S., 2001. Biophysical, chemical and socioeconomic indicators for assessing agricultural sustainability in the Chinese coastal zone. Agric. Ecosyst. Environ. 87, 209-214.

Ogden, C.B., van Es, H.M., Schindelbeck, R.R., 1997. Miniature rain simulator for field measurement of soil infiltration. Soil Sci. Soc. Am. J. 61, 1041-1043.

Payraudeau, S., van der Werf, H.M.G., 2005. Environmental impact assessment of a farming region: a review of methods. Agric. Ecosyst. Environ. 107, 1-10.

Riley, J., 2001. The indicator explosion: local needs and international challenges. Agric. Ecosyst. Environ. 87, 119-120.

Sepp, K., Bastian, O., 2007. Studying landscape change: indicators, assessment and application. Landscape Urban Plann. 79, 125-126.

Soil Survey Division Staff, 1993. Soil Survey Manual. Soil Conservation Service. US Department of Agriculture Handbook 18, US Government Printing Office, Washington DC.

Soil Survey Staff, 1999. Soil Taxonomy. A Basic System of Soil Classification for Making and Interpreting Soil Surveys, second ed. USDA-NRCS. Agriculture Handbook 436. US Government Printing Office, Washington, DC.

Sojka, R.E., Upchurch, D.R., 1999. Reservations regarding the soil quality concept. Soil Sci. Soc. Am. J. 63, 1039-1054.

van Es, H.M., Ogden, C.B., Hill, R.L., Schindelbeck, R.R., Tsegaye, T., 1999. Integrated assessment of space, time, and management-related variability of soil hydraulic properties. Soil Sci. Soc. Am J. 63, 1599-1608.

Weil, R.R., Islam, K.R., Stine, M.A., Gruver, J.B., Samson-Liebig, S.E., 2003. Estimating active carbon for soil quality assessment: a simplified method for lab and field use. Am. J. Altern. Agric. 18, 3-17.

White, R.E., 2003. Soils for Fine Wines. Oxford University Press, New York.

Wienhold, B.J., Andrews, S.S., Karlen, D.L., 2004. Soil quality: a review of the science and experiences in the USA. Environ. Geochem. Health. 26, 89-95.

Williams, J.R., Kissel, D.E., 1991. Water percolation: an indicator of nitrogen leaching potential. In: Follet, R.F., Keeney, D.R., Cruse, R.M. (Eds.), Managing Nitrogen for Groundwater Quality and Farm Profitability. Soil Science Society of America, Madison, WI, pp. 59-83.

Wright, S.F., Upadhyaya, A., 1998. A survey of soils for aggregate stability and glomalin, a glycoprotein produced by hyphae of arbuscular mycorrhizal fungi. Plant Soil 198, 97-107. 